\title{
Mental Health Predictors among Malaysians during Economic Crisis: The 3Fs Influence
}

\author{
${ }^{1 *}$ Naffisah Mohd Hassan, ${ }^{2}$ Siti Noorsuriani Maon, ${ }^{3}$ Erne Suzila Kassim \\ Faculty of Business and Management, Universiti Teknologi MARA \\ 42300 Puncak Alam, Selangor, MALAYSIA
}

\begin{abstract}
History has shown there is a significant effect of economic condition and mental health. Mental health plays an important role for individuals to have an adequate level of sanity in thinking and making decision. Thus, individuals with mental health problems will be easily disturbed and emotionally weak in coping up with daily issues related to money. While reports have shown the important roles of social support to the society during economic crisis, how a person copes with the changes and their influence to the mental health in Malaysia still requires a better understanding. Therefore, built on the justice theory, the study attempts to examine the roles of financial stress, financial behavior and financial wellbeing (the 3Fs) in explaining for one's ability to be mentally healthy. A total of 423 usable data gathered from working adults were analysed for both the measurement and structural models. The findings indicate significant relationships between the 3Fs and mental health during financial crisis. Thus, it could be concluded financial stress, financial behavior and financial wellbeing are important in determining one's ability to be able to cope with financial challenges.
\end{abstract}

Keywords: Mental health, financial stress, financial behaviour, and financial wellbeing

\section{Background}

Economic crises are common. An economic crisis is the phenomenon in which the country experiences a sudden economic downturn triggered by the financial crisis (Hausman \& Johnston, 2014). This phenomenon further leads to national inflation or deflation. While some argues the economic crisis is a national issue, and it is the responsibilities of the governing bodies to implement policies and strategies, every single person of the society is also responsible for their wellbeing. The economic crisis does not only make people feel distressed, (Fener, Cevik, \& Finance, 2015) but also makes some social changes to the community (Aytaç, Rankin, \& İbikoğlu,

2015). Companies cut down their manpower resulting in people's status change from economicallystable to jobless; and that is a life-changing moment.

Therefore, it is unarguable people need to prepare some financial cushion that will protect them in the event of an economic downfall (Lusardi \& Mitchell, 2014). However, we can learn the perseverance and the mental health of that Malaysian have in the past. The first thing when we hear the term 'mental health', the first thing come out in our mind is that the mental health is the same with psychological health (Houben, Van Den Noortgate, \& Kuppens, 2015). The purpose of this study is to investigate how financial stressor, financial behaviour and financial wellbeing examine as predictor factors to mental health resilience during economic crisis.

\section{Literature Review}

\subsection{Mental health during the economy turbulence}

Economy growth and mental health among individual in Malaysia is closely related especially among young adults who are represented by fresh graduates looking for stable income. Although majority 
of studies concerned adults, several empirical studies focus on the consequences of youth unemployment on mental health (Frasquilho, de Matos, Marques, Gaspar, \& Caldas-de-Almeida, 2017) as well as the increased risks of mental health problems among children with unemployed parents (Strandh, Winefield, Nilsson, \& Hammarström, 2014). According to the National Health and Morbidity Survey (2015) the prevalence of mental health problems among young adults (aged between 16 and 35) in Malaysia in 2015 was $29.2 \%$, which was a three-fold increase from $10.7 \%$ in 1996 (Nadia, 2018). Furthermore based on the study it was concluded many fresh graduates dream big for living in richness, while in reality struggling for lives and being financially independence are challenging them. Thus, this would lead to the number of rising depression, anxiety or other mental health problems.

Young, Dietrich, \& Nursing (2015) studied about psychological processes and family finances. It was found many adults worry about their family financial conditions. Being worried is actually a common phenomenon or situation among adults, and, more importantly, worry can be related to mental health problems which specifically include anxiety and depression both cross-sectionally and longitudinally (Young et al., 2015). There are many factors influencing mental health states of ones minds. The next section discussed on the investigated factors as mental health predictors during financial crisis.

\subsection{The factors influence mental health}

\subsubsection{Financial stress}

Financial stress is one of the factors that influence the individual mental health in Malaysia. Numerous countries that experienced an economic downturns since the Global Financial Crisis (GFC) have refocused their attention on the psychological effects of financial hardship on individuals and families (Taylor, Stevens, Agho, \& Raphael, 2017). Within such contexts, job loss, reduction of income, and associated housing stress can lead to increase levels of distress, depression, and anxiety. There has been little research to establish the psychological effects of economic "tough times," such as the post-GFC period, on family life in Australia, particularly families with dependent children and greater exposure to economic downturns (Sargent-Cox, Butterworth, Anstey \& Medicine, 2011).

Better understanding can be achieved by investigating coping in this context and how it may assist the development of strategies to support oneself under financial strain. More importantly, knowing how to mitigate the adverse effect of stress on family members. Prawitz, Kalkowski, Cohart, \& Issues (2013) studied on the financial stress and low family income. The findings indicate there are financial pressure among individual and families who are having middle-income and low-income. Therefore, cutting the costs and making a budgeting decision on their consumption is essential.

\subsubsection{Financial behaviour}

There are two contradictory points of views from researchers who mainly focus on knowledge and behaviour. One claimed that knowledge and confidence influence financial behaviours, and surprisingly, the effect of financial confidence on behaviours is just as important as the effect of financial knowledge (Tokar Asaad, 2015). Meanwhile, another article claims that one needs a decent handling of financial concept which needs to have an objective financial knowledge before embracing capable financial behaviour (Tang \& Baker, 2016). However, in normal situation, comprehending what to do does not guarantee ideal conduct. For instance, considering the complexities of individual financial decision-making, starting the procedure of capable financial 
activities can be scary, and here and now disappointments or diversions can undermine mindful longterm financial behaviours (Lees, 2016). People need to know financial concepts or ideas well and also have persisting constructive self-recognition as passionate assets. This will help spur practices in such a saddling setting and leads to good financial behaviours.

\subsubsection{Financial wellbeing}

In current years, the concept of wellbeing has been contributed to the growth of academic interest with implication for life, work and productivity. It can be understandable in view of information that enhances well-being that shows a severe preoccupation between individuals, economists, educators, and policy-makers alike. Financial well-being is important for human growth. Conferring to Brüggen, Hogreve, Holmlund, Kabadayi and Löfgren (2017), financial wellbeing is defined as the perception of being able to maintain the current situation and aligned with desired living standards and financial freedom. Financial wellbeing leads to controlled individual finance, having the ability to adapt with financial crisis, being able to achieve the financial goals and having a happy choices to make his or her own financial plan (Bureau, 2015). According to Vosloo, Fouché and Barnard (2014), financial well-being is defined as an objective and subjective concept that contributes to a person's assessment of his/her current financial situation. Based on the discussion, three hypotheses were formulated, which are:

H1: Financial stress influences individual's mental health during economic crisis

H2: Financial behavior influences individual's mental health during economic crisis H3:

Financial wellbeing influences individual's mental health during economic crisis

The prediction is illustrated in the conceptual model in Figure 1.

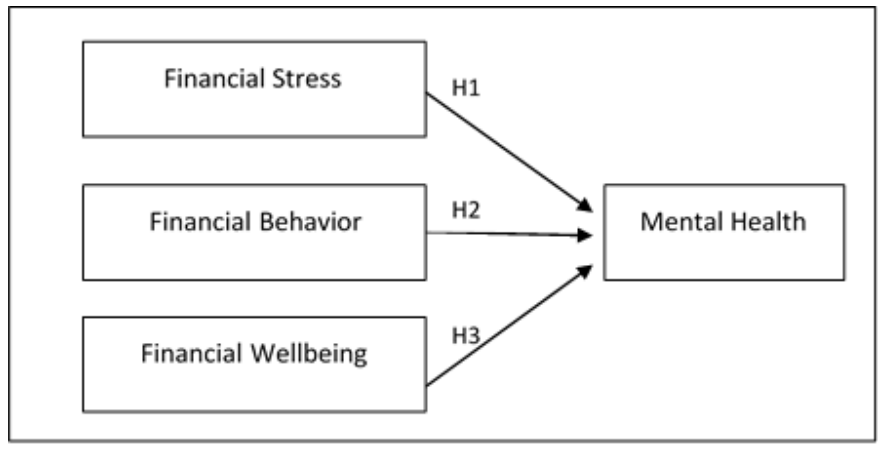

Figure 1: Conceptual Model

\section{Methodology}

\subsection{Population, Sample size and Instrumentation}

The survey method was employed to collect primary data from the community in Malaysia. Prior to the actual data collection, face and content validity and reliability tests were performed on 30 respondents. The obtained data were analyzed using SmartPLS which is a professional statistical software package that enables users to do Structural Equation Modeling or PLS path modeling. The results of the reliability test show the Cronbach alpha was above 0.65 . Therefore, the internal consistency was assumed (Hair, Black, Babin, Anderson, \& Tatham, 2006). Overall, 423 respondents who fit the as the target group, aged between 18 to 58 years old took part in the study. 


\subsection{Respondents' Demographic Profile}

A descriptive analysis was conducted to describe the demographic background of the respondents. The demographic profiles of the respondents are shown in Table 1. Referring to Table 1, the data results showed that more than half of the respondents were male $(n=283 ; 66.9 \%)$ and married $(n=251$; $59.3 \%)$. In terms of income, over half of the respondents is in the B40 category $(n=225 ; 53.2 \%)$ and this is consistent with the criteria of household income $(n=172 ; 40.7 \%)$. Majority of the respondents held a degree $(n=226 ; 53.4$. Majority of the respondents stay in the urban area $(n=239 ; 56.5)$ with average number of family members between three and six people.

Table 1: Demographic Profiles of the Respondents

\begin{tabular}{|c|c|c|c|c|c|}
\hline Variable & Frequenc $y$ & $\%$ & Variable & $\begin{array}{c}\text { Freque } \\
\text { ncy }\end{array}$ & $\%$ \\
\hline Gender & & & Marital Status & & \\
\hline Male & 283 & 66.9 & Single & 169 & 40.0 \\
\hline Female & 140 & 33.1 & Married & 251 & 59.3 \\
\hline Ethnicity & & & Divorced & 3 & .7 \\
\hline Malay & 405 & 95.7 & Personal Income & & \\
\hline Chinese & 13 & 3.1 & $\begin{array}{l}R M 0-R M 3000 \\
(B 40)\end{array}$ & 225 & 53.2 \\
\hline Indian & 3 & .7 & $\begin{array}{l}R M 3001-R M 6275 \\
(M 40)\end{array}$ & 153 & 36.2 \\
\hline Others & 2 & .5 & $\begin{array}{l}R M 6726 \text { - RM13148 } \\
(T 20)\end{array}$ & 45 & 10.6 \\
\hline Occupation & & & Household Income & & \\
\hline Government & 174 & 41.1 & $\begin{array}{l}R M 0-R M 3000 \\
(B 40)\end{array}$ & 172 & 40.7 \\
\hline Private & 183 & 43.3 & $\begin{array}{l}R M 3001- \\
R M 6275(M 40)\end{array}$ & 129 & 30.5 \\
\hline $\begin{array}{l}\text { Self- } \\
\text { employed }\end{array}$ & 59 & 13.9 & $\begin{array}{l}R M 6726-R M 13148 \\
(T 20)\end{array}$ & 122 & 28.8 \\
\hline Retired & 7 & 1.7 & $\begin{array}{l}\text { Residential } \\
\text { Area Rural }\end{array}$ & 94 & 22.2 \\
\hline Education Level & & & Sub Urban & 90 & 21.3 \\
\hline$S P M$ & 62 & 14.7 & Urban & 239 & 56.5 \\
\hline Diploma & 95 & 22.5 & No of household & & \\
\hline Degree & 226 & 53.4 & 0 & 2 & .5 \\
\hline Master & 32 & 7.6 & $1-2$ & 80 & 18.9 \\
\hline STPM & 3 & .7 & $3-4$ & 138 & 32.6 \\
\hline Foundation & 2 & .5 & $5-6$ & 139 & 32.9 \\
\hline Phd & 3 & .7 & More than 7 & 64 & 15.1 \\
\hline
\end{tabular}

\section{Assessment of measurement model}

The conceptual model was empirically tested 3 for confirming on the validity and reliability. The indicator loading, CR and AVE for the reflective constructs are shown in the Table 2. Some items were deleted due to low factor loadings and for the purpose of increasing the AVEs. Table 2 shows the deleted items. 
Table 2: Deleted Items

\begin{tabular}{ll}
\hline Construct & Items \\
\hline Financial Wellbeing & FB5: I cut down on living expenses \\
Mental Health & MH8: There are not enough hours in the day to accomplish everything I \\
want to do \\
MH9: I am losing confidence in myself. \\
MH10: I lost much sleep over worry. \\
MH11: My problems are usually caused by other people MH12: \\
I felt constantly under pressure. \\
MH13: I have a great support network. \\
MH14: I have been feeling loved by those people who knows me. \\
MH15: I am feeling optimistic about the future
\end{tabular}

The rest of the item loadings exceed the minimum recommendation value of 0.6 , which is required for an exploratory study (Ramayah et al., 2018). Based on the results shown in Table 3, all constructs meet the minimum value of the threshold requirement of composite reliability (CR) $>0.7$ and average variance extraction (AVE) are greater than 0.5 (Hair et al., 2014).

Table 3: Internal Consistency and Convergent Validity

\begin{tabular}{|c|c|c|c|c|c|c|}
\hline Constructs & Mean & Std Dev & Loadings & $\begin{array}{l}\text { Cronbach } \\
\text { alpha }\end{array}$ & AVE & $\mathbf{C R}$ \\
\hline Financial Behavior & & & & 0.837 & 0.891 & 0.672 \\
\hline $\begin{array}{l}\text { FB1: I developed a plan for my } \\
\text { financial future }\end{array}$ & 3.775 & 1.096 & 0.820 & & & \\
\hline $\begin{array}{l}\text { FB2: I started or increased my } \\
\text { savings }\end{array}$ & 3.757 & 1.091 & 0.841 & & & \\
\hline $\begin{array}{l}\text { FB3: I reduced some of my personal } \\
\text { debts }\end{array}$ & 3.697 & 1.108 & 0.815 & & & \\
\hline $\begin{array}{l}\text { FB4: I followed a budget or spending } \\
\text { plan }\end{array}$ & 3.461 & 1.037 & 0.801 & & & \\
\hline Financial Stress & & & & 0.904 & 0.924 & 0.635 \\
\hline $\begin{array}{l}\text { FS1: I am not able to purchase } \\
\text { clothing }\end{array}$ & 1.976 & 1.098 & 0.781 & & & \\
\hline $\begin{array}{l}\text { FS2: I am not able to discuss } \\
\text { financial matters. }\end{array}$ & 2.184 & 1.067 & 0.778 & & & \\
\hline $\begin{array}{l}\text { FS3: I am not able to pay the } \\
\text { utilities. }\end{array}$ & 1.882 & 1.094 & 0.785 & & & \\
\hline $\begin{array}{l}\text { FS4: I am not able to save for } \\
\text { emergencies }\end{array}$ & 2.402 & 1.241 & 0.740 & & & \\
\hline $\begin{array}{l}\text { FS5: I have financial concerns that } \\
\text { affect relationships. }\end{array}$ & 2.007 & 1.143 & 0.783 & & & \\
\hline $\begin{array}{l}\text { FS6: I have no money for medical } \\
\text { bills }\end{array}$ & 2.175 & 1.16 & 0.865 & & & \\
\hline $\begin{array}{l}\text { FS7: I am not able to keep a car } \\
\text { running. }\end{array}$ & 2.080 & 1.190 & 0.839 & & & \\
\hline
\end{tabular}




\begin{tabular}{|c|c|c|c|c|c|c|}
\hline Financial Well-being & & & & 0.666 & 0.809 & 0.586 \\
\hline Constructs & Mean & Std Dev & Loadings & $\begin{array}{l}\text { Cronbach } \\
\text { alpha }\end{array}$ & AVE & $\mathbf{C R}$ \\
\hline $\begin{array}{l}\text { FWB1: Satisfaction with personal } \\
\text { financial situation }\end{array}$ & 3.775 & 1.096 & 0.827 & & & \\
\hline FWB2: Perceived financial wellness & 3.757 & 1.091 & 0.723 & & & \\
\hline $\begin{array}{l}\text { FWB3: I know about my current } \\
\text { financial situation }\end{array}$ & 3.697 & 1.108 & 0.742 & & & \\
\hline Mental Health & & & & 0.946 & 0.956 & 0.758 \\
\hline $\begin{array}{l}\text { MH1: I am in a good physical } \\
\text { condition. }\end{array}$ & 4.064 & 0.967 & 0.783 & & & \\
\hline $\begin{array}{l}\text { MH2: I am in a good emotional } \\
\text { condition. }\end{array}$ & 3.939 & 0.928 & 0.874 & & & \\
\hline $\begin{array}{l}\text { MH3: I am able to enjoy my normal } \\
\text { day to day activities. }\end{array}$ & 3.950 & 0.948 & 0.885 & & & \\
\hline $\begin{array}{l}\text { MH4: I am able to concentrate on } \\
\text { what I am doing. }\end{array}$ & 3.868 & 0.941 & 0.888 & & & \\
\hline $\begin{array}{l}\text { MH5: I feel capable of making } \\
\text { decisions about things }\end{array}$ & 3.998 & 0.863 & 0.889 & & & \\
\hline MH6: I cope well with changes. & 3.934 & 0.912 & 0.892 & & & \\
\hline $\begin{array}{l}\text { MH7: I am able to face up to my } \\
\text { problem }\end{array}$ & 3.946 & 0.858 & 0.877 & & & \\
\hline
\end{tabular}

Next, a discriminant validity procedure was conducted to observe how the constructs are truly distinct from one another. This is achieved by assessing the cross loading criterion, Fornell and Larcker's (1981) criterion and Heterotrait-Monotrait ratio of correlations (HTMT). Based on the results shown in Table 4, there is a clear evidence of the discriminant validity establishment following the suggestions of Kline (2004) and Gold et al., (2001). The square-root of the AVEs of all latent variables which are shown in bold are higher than the correlations on other variables. As there has been criticism on the usage of Fornell-Lacker's (1981) criterion to detect discriminant validity, HTMT Ratio correlations that offers a stringent of better discriminant criterion was used. The results of the HTMT inference using bootstrapping confidence interval technique are less than 1 . Therefore, it is confirmed every construct is truly distinct from one another.

Table 4: HTMT Criterion and Variance Inflation Factor (VIF)

\begin{tabular}{lrrrrr}
\hline & $\begin{array}{l}\text { Financial } \\
\text { Behavior }\end{array}$ & $\begin{array}{l}\text { Financial } \\
\text { Stress }\end{array}$ & $\begin{array}{l}\text { Financial } \\
\text { Well } \\
\text { being }\end{array}$ & $\begin{array}{l}\text { Mental } \\
\text { Health }\end{array}$ & VIF \\
Financial Behavior & $\mathbf{0 . 8 2 0}$ & & & & 1.303 \\
Financial Stress & 0.226 & $\mathbf{0 . 7 9 7}$ & & & 1.089 \\
Financial Well being & 0.610 & 0.365 & $\mathbf{0 . 7 6 6}$ & & 1.360 \\
Mental Health & 0.570 & 0.271 & 0.615 & $\mathbf{0 . 8 7 0}$ & \\
& & & & & \\
\hline
\end{tabular}


In addition, prior to the structural model development, a procedure for addressing the collinearity issue was conducted. Pallant (2011) suggested the existence of multicollinearity does not contribute to a good regression model and the value of VIF should be assessed. Hair et la., (2011) suggested that VIF value of 5 or higher indicates a potential collinearity problem while Diamantopoulos and Siguaw (2006) suggested a more stringer criterion of VIF less than 3.3. Following both, the results in Table 4 indicate multicollinearity is not an issue in this study since the VIF values for all the constructs are less than 3 . The next step is to proceed with the structural model and hypothesis testing.

\section{Results and Findings}

In order to test the hypotheses, PLS algorithm was used with a bootstrapping resampling technique of 1000 sub-samples for ensuring the accuracy of the PLS estimates as recommended by Hair et al., (2014). The results of one-tailed path coefficients are shown in Table 5. Following Hair et al., (2017) for acceptance of $t$ value $>1.2645$ for $p$ value $<0.05$, it was found financial behavior $(B=0.328, p<$ $0.001)$, financial stress $(\beta=-0.098, \mathrm{p}<0.05)$ and financial wellbeing $(\beta=0.341, \mathrm{p}<0.001)$ play their roles as mental health predictors during financial crisis. Thus, it could be concluded $\mathrm{H} 1, \mathrm{H} 2$ and $\mathrm{H} 3$ were supported.

Next, the value of coefficient of determination $\left(\mathrm{R}^{2}\right)$ of 0.371 suggests the exogenous constructs explain $37.1 .0 \%$ of variances in mental health predictors during financial crisis, which Chin et al., (1998) considered as moderate. In addition, the effect size $\left(\mathrm{f}^{2}\right)$ of 0.131 for financial behavior, 0.014 for financial stress and 0.136 for financial wellbeing indicate small effect size to the study (Kenny, 2016) Additionally, the $\mathrm{f}^{2}$ values that represent the effect size of a specific exogenous construct on the endogenous construct Hair et al., (2016) were also assessed. Finally, the predictive relevance Q2 of 0.258 indicates the model has predictive relevance based on the exogenous variable.

Table 5: Path Coefficient Assessment and Determination of Coefficient $\left(\mathrm{R}^{2}\right)$ and Effect Size $\left(\mathrm{f}^{2}\right)$

\begin{tabular}{lccccccc}
\hline Hypothesis & $\begin{array}{l}\text { Std } \\
\text { Beta }\end{array}$ & $\begin{array}{l}\text { Std } \\
\text { Error }\end{array}$ & $\begin{array}{l}\text { T } \\
\text { value }\end{array}$ & Decision & $\mathbf{R}^{2}$ & $\mathbf{f}^{2}$ & $\mathbf{Q}^{2}$ \\
\hline $\begin{array}{l}\text { H1: Financial Behavior } \\
\text { and Mental Health }\end{array}$ & 0.328 & 0.051 & 6.361 & Supported & 0.371 & 0.131 & 0.258 \\
$\begin{array}{l}\text { H2: Financial Stress and } \\
\text { Mental Health }\end{array}$ & -0.098 & 0.041 & 2.393 & Supported & & 0.014 & \\
$\begin{array}{l}\text { H3: Financial Wellbeing and } \\
\text { Mental Health }\end{array}$ & 0.341 & 0.044 & 7.798 & Supported & & 0.136 & \\
$*^{* * *} \mathrm{p}<0.01,{ }^{* *} \mathrm{p}<0.05,{ }^{*} \mathrm{p}<0.10$ & & & & & & & \\
\hline
\end{tabular}

\section{Discussion}

The empirical findings of this study demonstrated all the three predictors' namely financial stress, financial behaviour, and financial wellbeing influence the mental health among working adults in Malaysia. The significant effect of financial stress on mental health shows the reality of many Malaysians' day-to-day struggles to go through this hardship crisis. The finding is consistent with past studies conducted that found mostly people's mental health in various income levels are affected by financial stress especially in countries with high cost of living (Balakrishnan, Danninger, Elekdag, Tytell, \& Trade, 2011; Prawitz et al., 2013; Taylor et al., 2017). From the findings, factors that contributed to financial stress include not having sufficient income, job loss and high prices of goods and services, which is consistent with a study by (Mokaya et al., 2013). All these will lead to stress 
in order to manage their finance or money for to pay up living cost and this will affect their mental health.

Based on the findings, financial behaviour is one of the key factors influencing mental health conditions. This study also reveals that by developing a plan for one's financial future, reducing personal debt, increasing saving and following a strict budget or spending plan among the key rules for good financial behavior. The finding is consistent with the studies conducted by Fernandes, Lynch $\mathrm{Jr}$ and Netemeyer (2014) and Tokar Asaad (2015). Considering the importance of individual financial decision-making, starting the procedure of capable financial activities can be scary, and here and now disappointments or diversions can undermine mindful long-term financial behaviors. People need to know financial concepts or ideas well and also have persisting positive selfrecognition as passionate assets.

Financial well-being is proportionate to good mental health (Vlaev \& Elliott, 2014). Actually, financial well-being is important for human growth. As discussed in literature review, conferring to Brüggen et al. (2017), financial well-being is the perception of being able to maintain the current and aligned with desired living standards and financial freedom. The findings also reveal that people in general always feel stress, anxiety and feel limited about their financial as they have to pay for their living cost, thus the financial well-being is definitely associated with mental health among Malaysians which is consistent with others studies (Brüggen et al., 2017; Bureau, 2015; Santiago, Wadsworth, \& Stump, 2011).

\section{Conclusion, Implications and Future Research}

The current study examines the influence of three predictors namely financial stress, financial behaviour, and financial wellbeing influence on mental health among Malaysians. Overall, the present study provides further insight pertaining to the factors influencing the mental health conditions among working adults in Malaysia. This study provides some key issues for the current conditions among society mental health during the period of economic turbulence and crisis. This finding demonstrates the importance of coping with financial stress such as not enough money for essential expenses, having good financial behaviour and understanding ones financial conditions can lead to healthy mental health conditions. Finally, future researchers are suggested to expand this study by looking at different levels of individual's income as it may yield different results and comparison between areas of living could be established. Also, future research may consider integrating relevant moderating variables to enhance the current research framework.

\section{References}

Alappatt, M., Shaikh, J. M. J. I. i. B. M., \& Economics. (2014). Forthcoming procedure of goods and service tax (GST) in Malaysia. 2(12), 210-213.

Aytaç, I. A., Rankin, B. H., \& İbikoğlu, A. J. S. I. R. (2015). The social impact of the 2008 global economic crisis on neighborhoods, households, and individuals in Turkey. 124(1), 1-19.

Balakrishnan, R., Danninger, S., Elekdag, S., Tytell, I. J. E. M. F., \& Trade. (2011). The transmission of financial stress from advanced to emerging economies. 47(sup2), 40-68.

Brüggen, E. C., Hogreve, J., Holmlund, M., Kabadayi, S., \& Löfgren, M. J. J. o. B. R. (2017). Financial well-being: A conceptualization and research agenda. 79, 228-237.

Bureau, C. F. P. J. R., Iowa City, IA: Consumer Financial Protection Bureau. (2015). Financial wellbeing: The goal of financial education.

Córdoba-Doña, J. A., Escolar-Pujolar, A., San Sebastián, M., \& Gustafsson, P. E. J. B. p. h. (2016). 
How are the employed and unemployed affected by the economic crisis in Spain? Educational inequalities, life conditions and mental health in a context of high unemployment. 16(1), 267.

Fener, T., Cevik, T. J. P. E., \& Finance. (2015). Leadership in Crisis Management: Separation of Leadership and Executive Concepts. 26, 695-701.

Fernandes, D., Lynch Jr, J. G., \& Netemeyer, R. G. J. M. S. (2014). Financial literacy, financial education, and downstream financial behaviors. 60(8), 1861-1883.

Frasquilho, D., de Matos, M., Marques, A., Gaspar, T., \& Caldas-de-Almeida, J. J. P. h. (2017). Factors affecting the well-being of adolescents living with unemployed parents in times of economic recession: findings from the Portuguese HBSC study. 143, 17-24.

Hair, J. F., Black, W. C., Babin, B. J., Anderson, R. E., \& Tatham, R. L. (2006). Multivariate data analysis (6th ed.). Upper Saddle River, N.J.: Pearson Prentice Hall.

Hausman, A., \& Johnston, W. J. (2014). Timeline of a financial crisis: Introduction to the special issue. In: Elsevier.

Houben, M., Van Den Noortgate, W., \& Kuppens, P. J. P. b. (2015). The relation between shortterm emotion dynamics and psychological well-being: A meta-analysis. 141(4), 901. Jaafar,

S. N., Lalp, P. E., Naba, M. M. J. A. J. o. B., \& Sciences, M. (2012). Consumers' perceptions, attitudes and purchase intention towards private label food products in Malaysia. 2(8), 73-90.

Lees, M. J. (2016). When it comes to behaviour, isn't it time for young people to be seen and heard. Middlesex University,

Lusardi, A., \& Mitchell, O. S. J. J. o. e. 1. (2014). The economic importance of financial literacy: Theory and evidence. 52(1), 5-44.

Prawitz, A. D., Kalkowski, J. C., Cohart, J. J. J. o. F., \& Issues, E. (2013). Responses to economic pressure by low-income families: Financial distress and hopefulness. 34(1), 29-40.

Santiago, C. D., Wadsworth, M. E., \& Stump, J. J. J. o. E. P. (2011). Socioeconomic status, neighborhood disadvantage, and poverty-related stress: Prospective effects on psychological syndromes among diverse low-income families. 32(2), 218-230.

Sargent-Cox, K., Butterworth, P., Anstey, K. J. J. S. s., \& medicine. (2011). The global financial crisis and psychological health in a sample of Australian older adults: a longitudinal study. 73(7), 1105-1112.

Strandh, M., Winefield, A., Nilsson, K., \& Hammarström, A. J. T. E. J. o. P. H. (2014). Unemployment and mental health scarring during the life course. 24(3), 440-445.

Taylor, M., Stevens, G., Agho, K., \& Raphael, B. J. I. J. o. P. R. (2017). The Impacts of Household Financial Stress, Resilience, Social Support, and Other Adversities on the Psychological Distress of Western Sydney Parents. 2017.

Tokar Asaad, C. J. F. S. R. (2015). Financial literacy and financial behavior: Assessing knowledge and confidence. 24(2).

Vlaev, I., \& Elliott, A. J. S. I. R. (2014). Financial well-being components. 118(3), 1103-1123.

Vosloo, W., Fouché, J., \& Barnard, J. (2014). The relationship between financial efficacy, satisfaction with remuneration and personal financial well-being. Citeseer,

Young, C. C., Dietrich, M. S. J. J. o. C., \& Nursing, A. P. (2015). Stressful life events, worry, and rumination predict depressive and anxiety symptoms in young adolescents. 28(1), 35-42.

Ramayah, T., Jacky Cheah, Francis Chuah, Hiram Ting, and Mumtaz Ali Memon. (2018). "Partial Least Squares Structural Equation Modeling (PLS-SEM) using SmartPLS 3.0: An Updated Guide

Hair, Joseph F., William C. Black, Barry J. Babin, and Rolph E. Anderson. "Multivariate data analysis . Harlow." (2014).

Kline, Rex B. "Principles and practice of structural equation modeling, New York: Guildford." (2004). 
Gold, Andrew H., Arvind Malhotra, and Albert H. Segars. "Knowledge management: An organizational capabilities perspective." Journal of management information systems 18 , no. 1 (2001): 185-214.

Pallant, J. (2011). For the SPSS Survival Manual: A step by Step Guide to Data Analysis using IBM SPSS (6th ed). New York: Mc Graw Hill Education.

Hair, Joe F., Christian M. Ringle, and Marko Sarstedt. "PLS-SEM: Indeed a silver bullet." Journal of Marketing theory and Practice 19, no. 2 (2011): 139-152.

Diamantopoulos, Adamantios, and Judy A. Siguaw. "Formative versus reflective indicators in organizational measure development: A comparison and empirical illustration." British Journal of Management 17, no. 4 (2006): 263-282.

Hair, Joseph F., William C. Black, Barry J. Babin, and Rolph E. Anderson. "Multivariate data analysis . Harlow." (2014).

Hair, Joseph F., G. Tomas M. Hult, Christian M. Ringle, Marko Sarstedt, and Kai Oliver Thiele. "Mirror, mirror on the wall: a comparative evaluation of composite-based structural equation modeling methods." Journal of the Academy of Marketing Science 45, no. 5 (2017): 616-632.

Kenny, David A. "Moderation." (2016).

Hair Jr, Joseph F., G. Tomas M. Hult, Christian Ringle, and Marko Sarstedt. A primer on partial least squares structural equation modeling (PLS-SEM). Sage Publications, 2016.

Nadia, B. (2018, January 23). Tackling mental health issues in young people. Retrieved from https://www.nst.com.my/lifestyle/ 